\title{
Medication Adherence and Social Support in Regards to Apprehension of Death in People Living with HIV/AIDS
}

\author{
Rachmawati \\ Psychology Study Program, Faculty of Medicine \\ Sriwijaya University
}

\begin{abstract}
Apprehension of death for People Living with HIV and AIDS (PLWA) is influenced by discipline in their adherence to their medication regimen and the social support they receive. This research aims to study the roles of discipline in adherence to their medication regimen and of social support, in regards to their apprehension of death, for PLWA. The data collection method employed a scale of discipline in adhering to a medication regimen, a scale of the social support received, and a scale of the apprehension of death. The subjects of this research were 89 people with positive HIV/AIDS status, living in South Sumatera. Data analysis was by multiple regression. The multiple regression analysis results indicated that both adherences to a medication regimen, and social support, play roles in regards to apprehension of death. $\left(R^{2}=0.113 ; F=5.473 ; p<.05\right)$. This research affirms the importance of internal and external factors in reducing the level of apprehension of death for PLWA.
\end{abstract}

Keywords: social support, apprehension of death, adherence to a medication regimen

Kecemasan terhadap kematian pada Orang dengan HIV/AIDS (ODHA) dipengaruhi oleh kepatuhan menjalani pengobatan dan dukungan sosial yang diterima. Penelitian ini bertujuan untuk menguji peranan kepatuhan menjalani pengobatan dan dukungan sosial terhadap kecemasan kematian pada ODHA. Metode pengumpulan data menggunakan skala kepatuhan menjalani pengobatan, skala dukungan sosial, dan skala kecemasan kematian. Subjek penelitian ini adalah orang dengan status HIV/AIDS positif di Sumatra Selatan berjumlah 89 orang. Analisis data menggunakan analisis regresi ganda. Hasil analisis regresi ganda menunjukkan bahwa kepatuhan menjalani pengobatan dan dukungan sosial secara bersama-sama memiliki peranan terhadap kecemasan kematian $\left(R^{2}=0.113 ; F=5.473 ; p<.05\right)$. Penelitian ini meneguhkan pentingnya faktor internal dan faktor eksternal dalam menurunkan tingkat kecemasan terhadap kematian pada ODHA.

Kata kunci: dukungan sosial, kecemasan kematian, kepatuhan menjalani pengobatan

Death is the inevitable end of life for all living creatures. Although time of death cannot be predetermined, none the less death may be predicted to give rise to apprehension in an individual, particularly for people suffering from chronic and difficult-to-cure illnesses, including people with AIDS. This agrees with the results of the research done by Lehto and Stein (2009), which clarified one of the antecedent variables related to a person's apprehension of death, after being diagnosed with a life-threatening disease.

It is supported also by Kemppainen et al. (2003, 2006, 2012), who elaborated on the results of a num-

Correspondence concerning this article should be addressed to Rachmawati, Psychology Study Program, Faculty of Medicine, Sriwijaya University, Jalan Raya Palembang-Prabumulih Km, 32 Inderalaya, Palembang 30662. E-mail: rama_psikologi@unsri.ac.id / ramana_ande@yahoo.com ber of pieces of research, performed jointly with his associates, finding many symptoms of apprehension amongst PLWA.

Amongst these many symptoms, the symptom of apprehension of death and fearfulness for the future was the one which most emerged in PLWA.

According to Firestone (2009), apprehension of death is a complex phenomenon, representing a combination of a number of emotions and thought processes, amongst these fear of death, horror of physical and mental breakdown, feelings of isolation, final experiences about fear of separation, sorrow about ending life, anger, and an feeling of extreme despair about a situation over which one has no control.

Comer (2013) differentiates between the terms anxiety/apprehension and fear. Anxiety/apprehension is 
a physiological and emotional response towards an unclear threat of danger, whilst fear is a physiological and emotional response towards a clear and serious threat, a threat against physiological welfare. Therefore, several experts have substituted the term 'fear of death' with the term 'apprehension/anxiety of death' (Kastenbaum, 2000). This can be comprehended because death is a clear threat, but becomes unclear when related to the questions of when, where, and how a person will die.

As it is a negative emotional reaction, triggered off by anticipation of the situation in which one will no longer exist (Nia et al., 2014), it is appropriately found in PLWA who, having just discovered that they have been infected with HIV, will experience shock, stress and serious depression, and indeed be inclined to commit suicide, because they consider they are about to die from HIV.

Templer et al. (2006) offer four factors as the basis for apprehension of death. These four factors are; (1) serious concern about death (pessimism); (2) fear of destruction; (3) feelings of suffering because of death; and (4) feelings they are about to cease to exist.

One of the ways to suppress the apprehension of death for PLWA is by instituting medication. Doctors and medical personnel indicate the principle need for PLWA is medication, although, according to Green (2015), the medication given merely suppresses the quantity of viruses in the body, as with antiviral therapy (ARV). Nonetheless, this medication has no meaning if it is not followed in a disciplined fashion, using the medication in an organized way, according to the instructions given by the doctor or medical team handling the case. This is similar to the matter of one by Plakas et al. (2016), who stated that adherence to the prescribed medication regimen is the way to improve a person's health, given the assumption that the medication is appropriate and correct.

Sarafino (1998) explained that discipline towards a medication regimen is a condition indicating just how far the patient carries on the activities and treatment recommended by his or her practitioner, in this case the doctor or other medical team member. In line with this, Unni and Farris (2011) also stated that adherence to a medication regimen indicates just how much the conduct of a person coincides with medical advice.

In the research performed by Alghurair, Hughes, Simpson, and Guirguis (2012), several factors were discovered, related to lack of strict adherence to the consumption of prescribed medication. The most important things were the patient himself or herself, the stage of the illness, management of the illness, the socio-economic status of the patient, and the health sys-tem, or health professionalism.

Antiretroviral (ARV) therapy in the medication of PLWA requires a high level of discipline, recalling that the viruses being combated will become resistant if the medication regimen is not executed with exactitude as regards dosage, amount and timing.

This is akin to the cases reported by Coughlin (2012), who said that PLWA need to abide by the rules of their medication, and to maintain life-long healthy behavior. It is this strict observation of an exact and ordered medication regimen which gives the biggest window of opportunity for PLWA to live a long time, free of the apprehension of death, and in a normal style, like other people, who are healthy.

The results of research from European countries regarding poor discipline in medication shows that it is related to low self-efficacy, the severity of perceived obstructions, expenses in relation to behavior, deleterious reactions to medication (effects) and the frequency of dosage delivery (Kardas et al., 2012).

Besides the medical treatment which may be given, to overcome any apprehension of death PLWA also require support from the social circles around them, because social support has close ties to health (Berkman, et al., 2000; Cohen, 2004; Smith \& Christakis, 2008, as cited in Neufeld \& Harrison, 2010).

According to Taylor, Peplau, and Sears (2009), social support is interpersonal exchange, characterized by emotional attention, instrumental assistance, the provision of information, or other assistance. Social support can certainly strengthen a person facing the effect of stress, and possibly can increase his or her physical health as well.

Long-term experimental studies, carried out over one year on PLWA by Rzeszutek, Oniszczenko, and Burkacka (2017) showed in one result that social support has a positive connection with individual experiences, related to positive changes in efforts to face major crises in life (post-traumatic growth/PTG), in this case the crisis being because of being HIV positive.

Because of this, and realizing the importance of the results of this research in assisting PLWA to be able to live a healthy, appropriate and productive life, both economically and socially, as well as to be free of the apprehension of death, this research was aimed at examining the roles of discipline in adherence to a medication regimen, and of social support, concerning the apprehension of death felt by PLWA. The hypothesis of this research is that there are roles 
for discipline in adherence to a medication regimen, and for social support, when confronting the apprehension of death, by PLWA.

\section{Method}

\section{Identification of Variables}

The variables in this research consisted of one tied variable, that is apprehension of death, and two free variables, these being adherence to a medication regimen, and social support.

\section{Subjects}

Data collection from the subjects was conducted with the assistance of the Yayasan Sriwijaya Plus (or YSP - the 'Sriwijaya Charity - Plus') acting as an assistant or guide to PLWA in South Sumatera. The subjects who were the sample for this research numbered 89 PLWA, whose characteristic is testing positive to HIV, and who have undergone or are undergoing ARV medication. The places of residence of the subjects are spread over a number of towns and cities in South Sumatera, and they comprise 54 males and 35 females. The ages of the subjects range from nine years to 54 years $(M=31.38, S D=7.75)$. The causative factors for them becoming PLWA are; free sex, 35 persons (39.33\%), contracted from partners, 32 persons (35.95\%), hypodermic needles, 14 persons $(15.73 \%)$, contracted from parent/s, two persons $(2.25 \%)$, blood transfusions, two persons $(2.25 \%)$, and unknown, four persons $(4.49 \%)$. The periods they have been aware of being HIV positive vary from three months to 18 years.

\section{Research Instruments}

The research instrument utilized were psychological scales, with responses in the Likert form, that is with four response choices: "Greatly Disagree" (value of 1), "Don't Agree" (value of 2), "Agree" (value of 3), and "Greatly Agree" (value of 4). The scales used were:

(1) The basic scale, 'Death Anxiety Scale-Extended' (DAS-E), from Templer et al. (2006), which was translated and brought into accord with the phenomena of the research. The original items numbered 27 , however, after item validation was performed, five items were declared failed, and 22 were declared valid. The reliability of the valid items was .921 . After this, the 22 valid items were used in the research;
(2) The discipline in adherence to the medication regimen scale, which was created by the researcher, with reference to the means of measuring discipline according to Sarafino (1998). In total, the original items numbered 34, however, after item validation was conducted, 13 items were declared failed, and 21 were declared valid. The reliability of the valid items was .917 . After this, the 21 valid items were utilized for the research;

(3) The social support scale, which was created by the researcher, with reference to the type of social support according to Sarafino (1998). The original items numbered 30, however, after item validation was conducted, six items were declared failed, and 24 were declared valid. The reliability of the valid items was .894. After this, the 24 valid items were utilized for the research.

The validity of the items from the three scales used a corrected item total correlation with a minimum of .3, and was tested on 25 PLWA as a test sample.

\section{Research Procedure}

The research was conducted after obtaining the permission of the chair of the YSP as the associate charity foundation for PLWA in South Sumatera. The YSP facilitated consent from, and meetings with, the subjects of the research, through the routine monthly activities of the PLWA, and at the same time spread the word on the research, whereby the researcher became a resource for a number of functions conducted by YSP. Printed informed consent forms were attached to the research scales, and these were signed as a form of agreement by those involved in the research. The written completion of the scales was performed by the subjects, accompanied by the researcher and/ or members of the YSP. Special accompaniment was organized for a PLWA aged under nine years, who was questioned before as to whether he/she was literate, to which the answer was in the affirmative. Then the mother of the subject, who is also a PLWA, together with assistants from the YSP, explained, sentence by sentence, what was contained in the scales, to ensure the subject understood the contents. Distribution of the scales was done during a number of meetings, inter alia: at the YSP office, which becomes a 'base camp' where the PLWA assemble at the times of the monthly YSP activities; at the homes of PLWA during visits, as well as during hospital visits where they went to take ARV medication. As tokens of thanks for their readiness to be research subjects, the PLWA were given rewards, in the form of alarm pill boxes. 
Table 1

Illustration of Distribution of Research Data Results

\begin{tabular}{lcccccccc}
\hline \multicolumn{1}{c}{ Variables } & \multicolumn{3}{c}{ Hypothetical Data } & \multicolumn{4}{c}{ Empirical Data } \\
& Max & Min & Mean & SD & Max & Min & Mean & SD \\
\hline Apprehension of Death & 88 & 22 & 55 & 11 & 75 & 29 & 51.13 & 10.248 \\
Discipline in Adherence to Medication Regimen & 84 & 21 & 52.5 & 10.5 & 83 & 40 & 67.42 & 8.125 \\
Social Support & 96 & 24 & 60 & 12 & 96 & 56 & 76.26 & 7.833 \\
\hline
\end{tabular}

\section{Data Analysis}

The data analysis for the research utilized parametric statistics by conducting testing of assumptions, comprising testing of normality, testing of linearity, testing of homoscedastisity and testing of multicollinearity, whilst testing of the hypotheses utilized multiple regression analysis.

\section{Results}

An illustration of the results of the research data can be seen in Table 1.

An illustration of the results of the categorization of the research subjects can be seen in Tables 2, 3, and 4.

The testing of assumptions made concerning the research instruments comprised testing of normality, testing of linearity, testing of homoscedastisity, and testing of multicollinearity. The testing of normality, utilizing the Kolmogorov-Smirnov testing method, produced the results shown in Table 5 and 6.

The linearity testing, referring to the test for linearity produced the results shown in Table 6 .

The testing of homoscedastisity was conducted by referring to a scatterplot graphic, as shown on Figure 1. From the scatterplot figure shown on Figure 1, the existence of heteroscedasticity is not apparent, because for every prediction value, the residual value has a similar

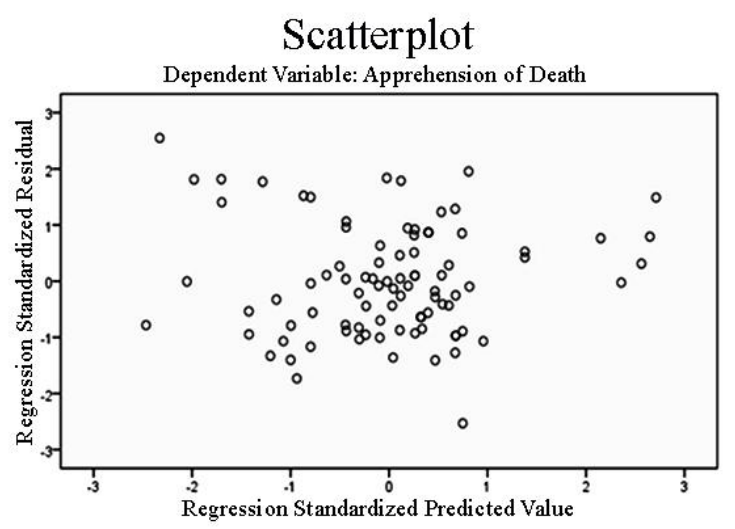

Figure 1. Testing of homoscedastisity.
Table 2

Apprehension of Death

\begin{tabular}{cccr}
\hline Score & Category & Frequency & Percentage \\
\hline $\mathrm{X}<44$ & Low & 22 & $24.72 \%$ \\
$44 \leq \mathrm{X}<66$ & Medium & 59 & $66.29 \%$ \\
$66 \leq \mathrm{X}$ & High & 8 & $8.99 \%$ \\
Total & & 89 & $100 \%$ \\
\hline
\end{tabular}

Table 3

Categorization of Discipline in Adherence to a Medication Regimen

\begin{tabular}{cccr}
\hline Score & Category & Frequency & Percentage \\
\hline $\mathrm{X}<42$ & Low & 1 & $1.12 \%$ \\
$42 \leq \mathrm{X}<63$ & Medium & 17 & $19.10 \%$ \\
$63 \leq \mathrm{X}$ & High & 71 & $79.78 \%$ \\
Total & & 89 & $100 \%$ \\
\hline
\end{tabular}

Table 4

Categorization of Social Support

\begin{tabular}{cccr}
\hline Score & Category & Frequency & Percentage \\
\hline $\mathrm{X}<48$ & Low & 0 & $0 \%$ \\
$48 \leq \mathrm{X}<72$ & Medium & 24 & $26.97 \%$ \\
$72 \leq \mathrm{X}$ & High & 65 & $73.03 \%$ \\
Total & & 89 & $100 \%$ \\
\hline
\end{tabular}

Table 5

Normality Testing

\begin{tabular}{cccc}
\hline Variable & K-SZ & Sig. & Status \\
\hline Apprehension of Death & .780 & .577 & Normal \\
$\begin{array}{c}\text { Discipline in Adherence to } \\
\text { Medication Regimen }\end{array}$ & .967 & .307 & Normal \\
$\quad$ Social Support & .988 & .283 & Normal \\
\hline
\end{tabular}

Table 6

Linearity Testing

\begin{tabular}{cccc}
\hline Variable & $F$ & $\frac{\text { Linearity }}{2}$ Status \\
\cline { 3 - 4 } Apprehension of Death & 11,553 & .001 & Linear \\
- & & & \\
$\begin{array}{c}\text { Discipline Adhering to } \\
\text { Medication Regimen }\end{array}$ & & & \\
$\begin{array}{c}\text { Apprehension of Death } \\
\quad-\end{array}$ & 11,421 & .001 & Linear \\
$\quad$ Social Support & & & \\
\hline
\end{tabular}


residual variation, tending to be constant and not indicating any special pattern.

The multicollinearity testing was conducted by observing the VIF and tolerance values, as shown in Table 7. From the multicollinearity testing (shown in Table 7), it is apparent that discipline in adhering to a medication regimen has a VIF value of $1.575(<10)$ and a tolerance of $.635(>0.01)$, whilst social support has a VIF value of $1.575(<10)$ and a tolerance of .635 (> .01), so it may be concluded that there is no multicollinearity problem with either free variable.

The correlation coefficient between discipline in adhering to a medication regimen and social support is .604 .

After the requirements of the assumption testing were fulfilled, hypothesis testing was conducted, using multiple regression analysis. The results of the multiple regression analysis were used to view the roles of combined discipline in adherence to a medication regimen, concerning apprehension of death. The results obtained from the data processing were shown in Table 8.

The results of the multiple regression (as shown in Table 8) indicate the size of the role of a combination of discipline in adherence to a medication regimen and social support, concerning apprehension of death, are $11.3 \%$, with an $F$ value of 5.473 ( $p$ $=.006<.05$ ), whilst the role of the discipline in adhering to a medication regimen variable, by controlling the social support variable, is apparently insignificant $(p=.133>.05)$. Such also is the case with the social support variable, which by controlling the discipline in adherence to a medication regimen variable, apparently is insignificant $(p=.157>.05)$, so that follow-up analysis to see the extent of the role of each free variable towards the tied variable could not be performed.

\section{Discussion}

The results of data analysis, using multiple regression testing, obtained the result that, jointly, the two variables, discipline in adherence to the medication regimen and social support, have a significant connection to the apprehension of death in PLWA in South Sumatera, whereby the strength of the connection is . 336 .

The results of this research are in line with the results of the research by Khan, Afroz, and Chakravarty (2011), who investigated HIV patients, where the patients were divided into two groups, those newly diagnosed as HIV positive, and so newly having begun to undergo ARV therapy, and those who had been undergoing ARV therapy for at least six months. The results of that research indicated that there is a negative correlation between social support and the apprehension of death felt by HIV sufferers, wherein the higher the degree of social support, the lower their apprehension of death.

This aside, results of the study of meta-analysis of eighteen pieces of research concerning apprehension of death in PLWA also indicated that, put simply, social support had a reverse proportional connection to apprehension of death (Miller, Lee, \& Henderson, 2012). Furthermore, Wendorf (2014) formed the conclusion that social support had a simple protective effect against the presence of the apprehension of death for PLWA. Other new research by Mehri Nejad, Rameezan, and Paydar (2017)

Table 7

Multicollinearity Testing

\begin{tabular}{|c|c|c|c|c|c|c|}
\hline \multirow{2}{*}{\multicolumn{2}{|c|}{ Model }} & \multicolumn{2}{|c|}{ Unstandardized Coefficients } & \multirow{2}{*}{$\begin{array}{l}\text { Standardized Coefficients } \\
\text { Beta }\end{array}$} & \multicolumn{2}{|c|}{ Collinearity Statistics } \\
\hline & & $B$ & Std. Error & & Tolerance & $V I F$ \\
\hline \multirow[t]{3}{*}{1} & (Constant) & 85.716 & 10.663 & & & \\
\hline & $\begin{array}{l}\text { Discipline in Adherence } \\
\text { to Medication Regimen }\end{array}$ & -.244 & 161 & -.193 & .635 & 1.575 \\
\hline & Social Support & -.238 & .167 & -.182 & .635 & 1.575 \\
\hline
\end{tabular}

Table 8

Results of Analysis of the Combined Multiple Regression of Variables, Regarding Apprehension of Death $(N=89)$

\begin{tabular}{|c|c|c|c|c|}
\hline Variable & $B$ & $S E B$ & $\beta$ & $\overline{S i g}$ \\
\hline $\begin{array}{l}\text { Discipline in adherence to medication } \\
\text { regimen }\end{array}$ & -.244 & .161 & -.193 & .133 \\
\hline Social support & -.238 & .167 & -.182 & .157 \\
\hline $\begin{array}{l}R^{2} \\
F\end{array}$ & & & & .006 \\
\hline
\end{tabular}


also indicated that there is a direct connection between social support and apprehension of death.

Contrary to the research conducted by Khan, Afroz, and Chakravarty (2011), which saw ARV therapy as being one of the forms of social support which can reduce apprehension of death for PLWA, this researcher observed that success in reducing apprehension of death for PLWA was located, not with the ARV therapy conducted, but in discipline in their adherence to an ARV medication regimen by PLWA. Therefore, in this matter, the researcher saw the variable of discipline in adherence to a medication regimen as being an independent variable, and not a part of the social support received by PLWA.

The hypothesis of the researcher was supported by the results of the research by Wendorf (2014), which examined the balance of social support in relation to depression, apprehension and discipline in adherence to a medication regimen amongst seroconcordant partners, wherein one of the results of the discoveries stated that discipline is viewed as a personal responsibility, and that the support felt did not play a significant role regarding discipline in adhering to a medication regimen.

As an independent variable, discipline in adherence to a medication regimen significantly influences apprehension. This hypothesis is supported by the results of the research in HIV clinics by Shacam, Morgan, Onen, Taniguchi, and Overton (2012), which discovered that the individuals not receiving ARV therapy showed greater symptoms of apprehension. In a further analysis, this discovery was connected to the low level of discipline, high viral loads, and the paucity of white blood cells, or T-4 Cells (CD4). Although this research did not explicitly clarify the form of apprehension emerging as a result of the low level of discipline, Kemppainen et al. (2003) discovered that, amongst many symptoms which emerged connected with HIV/AIDS status, the symptoms of apprehension of death and concern for the future are the most frequently emergent of the many other symptoms of apprehension.

Results of the research by Willie, Overstreet, Sullivan, Sikkema, and Hansen (2016), on female PLWA who had experienced sexual abuse as infants, also indicated that apprehension and depression have connections with ill discipline in adherence to HIV medication regimens, wherein those connections are of a negative characteristic. One of the forms of apprehension which emerged from their findings is apprehension of death.
The dearth of effective contributions given by the two free variables of this research can be seen from $R^{2}$ being 0.113 . This means that jointly, the variable of discipline in adhering to a medication regimen and that of social support have a role of only $11.3 \%$ in relation to apprehension of death for PLWA in South Sumatera. $88.7 \%$ of the influence comes from other factors, not examined in this research.

Kastenbaum $(2000,2003)$ reviewed a number of pieces of research conducted with people in general (non-clinical) and noted several factors connected with apprehension of death, inter alia: age, gender, religion and belief, as well as health. Meanwhile, Henderson (2009), who also conducted literary studies, saw several psychological factors which influenced apprehension of death, amongst these being; age, environment, religious conviction, integrity of the ego, self fulfillment, and feelings of being valuable.

Besides the small scale of the role indicated for the two free variables, jointly, in relation to the tied variable, the results of this research also indicated the absence of any significant role for either free variable, when the other free variable is controlled $(p=.133$ $>.05 ; p=.157>.05$ ). This could occur because of a strong connection between the discipline in adherence to a medication regimen variable, and the social support variable $(r=.604)$, although assumption testing did not indicate any multicollinearity problem for the two free variables (tolerance $=.635>0.1$; $V I F=1.575<10$ ).

The strength of the relationship between the two free variables may be caused because the ARV therapy (included in which is are medication, doctors' services and CD4 detection equipment, which is supplied free of cost) is part of the forms of social support (instrumental) supplied by the government to PLWA, as shown in the results of the research by Khan, Afroz, and Chakravarty (2011). Nonetheless, the relationship is of no use when ARV medication therapy is not followed up by discipline in adherence to the therapy, as is shown in the results of research by Wendorf (2014), which states that such discipline is seen as a private responsibility, and is support which is felt not to play a significant role regarding adherence to a medication regimen.

For this reason, in simple terms, the researcher concluded that discipline in adhering to a medication regimen has as its source internal factors (personal), whilst social support has as its source external factors. The two factors may intersect with one another, however they may also be unconnected. 
The categorization of the level of apprehension of death felt by PLWA in this research indicates that a large portion of them have a medium (66.29\%), tending to low (24.72\%), level of apprehension, and it is only a few (8.99\%) who have a high level of apprehension. This is reversely proportional to their discipline in adhering to their medication regimen, wherein a large portion of the PLWA have a high degree of discipline in adhering to their medication regimen (79.78\%), followed by those having a medium level of discipline to adherence (19.1\%), followed by those with a low level (1.12\%). This is the case too with the level of social support felt by PLWA, wherein a large portion feel a high level of social support (73.03\%), followed by those feeling a medium level $(26.97 \%)$.

The results of this categorization are in accord with a number of pieces of previous research, which discovered the existence of a negative correlation between the discipline in adhering to a medication regimen variable, the social support variable and the apprehension of death variable, whereby the higher the discipline adhering to a medication regimen, and of social support, was, the lower was the apprehension of death felt. These results of categorization are in accord with those obtained in this research, although the correlation results and the roles of the two variables of discipline in adherence to a medication regimen and social support appear to be small/low. A premise is advanced by this researcher, regarding the low level of correlation and the roles of the two variables, concerning the length of time PLWA have been aware that they are infected with HIV. In this research, 69.67\% of the PLWA had discovered that they were infected with the HIV more than one year previously, $14.61 \%$ had known for six months, and it was only $7.68 \%$ who had known they were infected with HIV for less than six months. All subjects have undergone ARV medication therapy.

It is premised that the length of the period between initial diagnosis of HIV, and the measurement of apprehension of death when this research was conducted, had enabled the PLWA to adjust themselves, so as to adapt, change their lifestyle and obtain information, so that eventually they were able to accept the presence of the virus within themselves. It is when they arrive at this stage of accepting the situation that the PLWA are free from feelings of guilt, from concern, can have a more positive outlook for the future, and are able to make the most of opportunities, as is the case with the majority of people.

Information obtained from one of the managers of the charity which stands by the PLWA in South
Sumatera, indicates that it takes around six months for the PLWA for whom they reach out to be able to accept the existence of their condition. Indeed, a number of them take less than six months, however in certain cases there are some who need more than a year to accept the fact that they have been infected with the HIV. This occurs with PLWA who, when contacted, have a CD4 below 200, thus needing extra management.

One of the PLWA said that he/she became resigned to the fact of the virus in his/her body because it was not possible to remove it. Information obtained about the HIV helped him/her to accept his/her own situation, that HIV was not as horrible as was imagined by ordinary people. PLWA may live normal lives, engage in activities as usual, be productive, like people who are not PLWA. The difference with people who are not PLWA is found only in the fact of the medication, which must be taken for life. None the less, as they are aware, there are sufferers of other illnesses who also must take medication for life, such as those with heart problems, hypertension, thyroid problems, mental disturbances and leukemia. It is this knowledge of other illnesses which subsequently cheers PLWA, because it is not only PLWA who will take medication all of their lives. A number of PLWA have admitted that the illness which they fear is no longer HIV, but high cholesterol and heart attacks, just like other, normal, people.

The premise of this researcher, concerning the role of the length of time since having been diagnosed with HIV for the first time, is supported by the results of the research conducted by Beydag (2012), who discovered differences in levels of apprehension of death amongst cancer patients, related to how long the patient had been diagnosed with cancer and undergone treatment. The results of the experiment indicated that patients who had been in the process of undergoing treatment for less than six months had a level of apprehension higher than those who had been undergoing treatment for longer than six months.

\section{Research Limitations}

Although PLWA in South Sumatera are recorded as numbering 2,975 to the end of 2016 (Department of Health R. I., 2017), nonetheless it was only 89 PLWA who were able to be participants in this research. The obstacle encountered is that a large portion of PLWA has concealed their HIV/AIDS status from people who are not PLWA. This aside, information concerning the residences of PLWA is unknown, and they are difficult to reach. 


\section{Conclusion}

On the basis of the results of this research, it may be concluded that the apprehension of death felt by PLWA is significantly influenced by their discipline in adherence to their medication regimen and the social support they receive. The higher the level of discipline in adherence to their medication regimen, as well as the higher the level of social support they receive, the lower the level of apprehension of death felt by PLWA. The length of time since becoming aware for the first time of being HIV positive, makes the possibility of social support they receive larger, and their level of discipline in adhering to their medication regimen greater.

\section{Recommendations}

Keeping in mind that ARV therapy is the only medication currently effective in preventing the HIV developing, it would be better if ARV medication were to be provided in hospitals or public health centers in the regions, because the constraints of distance and time are two of the factors behind a PLWA having the leeway to become negligent regarding his/her medication regimen, because of his/her medication supplies being exhausted. Besides this, support must continue to be provided, so as to increase awareness regarding patterns of healthy living, and their treatment not be limited just to ARV therapy.

A recommendation for future researchers is that they study other variables, such as self-acceptance, the length of time since a person has been being diagnosed with HIV, the acceptance of the environment around PLWA, religious convictions, and other matters. It is hoped that, with the increase in the amount of research covering PLWA, there will be an increase in the revelation of information concerning just what factors are required by PLWA to be able to increase their levels of physical and psychological health.

\section{References}

Alghurair, S. A., Hughes, C. A., Simpson, S. H., \& Guirguis, L. M. (2012). A systematic review of patient self-reported barriers of adherence to antihypertensive medications, using the World Health Organization multidimensional adherence model. The Journal of Clinical Hypertension, 14, 877-886. https://doi.org/10.1111/j.1751-7176.2012.00699.x
Beydag, K. D. (2012). Factors affecting the death anxiety levels of relatives of cancer patients undergoing treatment. Asian Pacific Journal of Cancer Prevention, 13, 2405-2408. https://doi.org/10.7314/ APJCP.2012.13.5.2405.

Comer, R. J. (2013). Abnormal psychology (8th ed.). New York: Worth Publishers.

Coughlin, S. S. (2012). Anxiety and depression: Linkages with viral diseases. Public Health Reviews, 34(2), 92-105.

Department of Health R. I. (2017). Laporan Perkembangan HIV-AIDS \& Penyakit Infeksi Menular Seksual (PIMS) Triwulan III Tahun 2016. Retrieved from http://www.siha.depkes. go.id/portal/files_upload/Final_Laporan_HIV_AI DS_TW-3_2016.pdf

Firestone, R. (2009). Beyond death anxiety. New York: Springer Publishing Company.

Green, C. W. (2015). Pengobatan untuk AIDS: Ingin mulai?. Jakarta: Yayasan Spiritia.

Henderson, L. (2009). Variables affecting death anxiety. Retrieved from http://home.wlu.edu/ whiti ngw/sampap.htm.

Kardas, P., Morrison, V., Fargher, E., Parveen, S., Plumpton, C., Clyne, N.,... Hughes, D. (2012). Report on the determinants of patient non-adherence with short-term therapies and treatment for chronic diseases in Europe. In Ascertaining barriers for compliance: Policies for safe, effective and costeffective use of medicines in Europe 2012, 40. Retrieved from http//www.ABCproject.eu

Kastenbaum, R. (2000). The psychology of death (3rd ed.). New York: Springer Publishing Company.

Kastenbaum, R. (2003). Macmillan: Encyclopedia of death and death. U.S.A.: Thomson Gale.

Kemppainen, J., Holzemer, W., Nokes, K., Eller, L., Corless, I., Bunch, E., \& Chou, F. Y. (2003). Selfcare management of anxiety and fear in HIV disease. Journal of Nurses in AIDS Care, 14, 21-29. https:// doi.org/10.1177/1055329002250958

Kemppainen, J., Eller, L., Bunch, E., Hamilton, M. J., Dole, P., Holzemer, W., \& Tsai, Y. F. (2006). Strategies for self-management of HIV-related anxiety. AIDS Care, 18s, 597-607. https://doi.org/10. 1080/09540120500275726

Kemppainen, J. K., Wantland, D., Voss, J., Nicholas, P., Kirksey, K. M., Corless, I. B., \& Maryland, M. (2012). Self-care behaviors and activities for managing HIV-related anxiety. Journal of The Association of Nurses in AIDS Care, 23, 111-123. https:// doi.org/10.1016/j.jana.2011.05.004 
Khan, H., Afroz, N., \& Chakravarty, J. (2011). Effect of social support on death anxiety among HIV positive people. Social Science International, 27(2), 219-226.

Lehto, R. H., \& Stein, K. F. (2009). Death anxiety: An analysis of an evolving concept. Research and Theory for Nursing Practice: An International Journal, 23(1), 23-41. https://doi.org/10.1891/15416577.23.1.23

Mehri Nejad, S. A., Rameezan, S. L., \& Paydar, S. (2017). Death anxiety, and its relationship with social support and adherence to religion, in the elderly (Persian). Iranian Journal of Ageing, 11(4), 494-503. https://doi.org/10.21859/sija-1104494

Miller, A. K., Lee, B. L., \& Henderson, C. E. (2012). Death anxiety in persons with HIV/AIDS: A systematic review and meta-analysis. Death Studies, 36, 640-663. https://doi.org/10.1080/07481187.20 11.604467

Neufeld, A., \& Harrison, M. J. (2010). Nursing and family care-giving: Social support and non-support. New York: Springer Publishing Company.

Nia, H. S., Ebadi, A., Lehto, R. H., Mousavi, B., Peyrovi, H., \& Chan, Y. H. (2014). Reliability and validity of the Persian version of Templer death anxiety, scale-extended in veterans of Iran-Iraq warfare. Iran Journal of Psychiatry Behavior Science, 8(4), 29-37.

Plakas, S., Mastrogiannis, D., Mantzorou, M., Adamakidou, T., Fouka, G., Bouziou, ..., Morisky, D. E. (2016). Validation of the 8-item Morisky medication-adherence scale in chronically ill ambulatory patients, in rural Greece. Open Journal of Nursing, 6, 158169. https://doi.org/10.4236/ojn.2016.63017

Rzeszutek, M., Oniszczenko, W., \& Burkacka, E. F. (2017). Social support, stress- coping strategies, resilience and post-traumatic growth in a Polish sam- ple of HIV-infected individuals: Results of a 1 year longitudinal study. Journal of Behavior Medication, 40, 942-954. https://doi.org/10.1007/s10865-0179861-z

Sarafino, E. P. (1998). Health psychology: Biopsychosocial interactions (3rd ed). New York: John Wiley \& Sons.

Shacam, E., Morgan, J., Onen N. F., Taniguchi, T. \& Overton, E. T. (2012). Screening anxiety in the HIV clinic. AIDS Behavior, 16(8), 2407-2413. https:// doi.org/10.1007/s10461-012-0238-6

Taylor S. E., Peplau, L. A., \& Sears, D. O. (2009). Psikologi sosial (12th ed., Tri Wibowo B. S., Trans.). Jakarta: Kencana Prenada Media Group.

Templer, D. I., Awadala, A., Al-Fayez, G., Fraze, J., Bassman, L., Connelly, H. J., ... Abdel-Khalek, A. M. (2006). Construction of a death-anxiety scale, extended. Omega, 53(3), 200-226.

Unni, E. J., \& Farris, K. B. (2010). Unintentional nonadherence and belief in medicines in older adults, patient education and counseling. Patient Education \& Counseling Journal, 83(2), 265-268. https:// doi.org/10.1016/j.pec.2010.05.006

Wendorf, A. R. (2014). Equity of social support and its relationship with depression, anxiety, and antiretroviral medication adherence among seroconcordant dyads of HIV positif African-Americans and their informal supporters (Unpublished doctoral dissertation). University of Wisconsin, Milwaukee.

Willie, T. C., Overstreet, N. M., Sullivan, T. P., Sikkema, K. J. \& Hansen, N. B. (2016). Barriers to HIV medication adherence: Examining distinct anxiety and depression symptoms, among women living with $\mathrm{HIV}$, who experienced childhood sexual abuse. $B e-$ havior Medication, 42(2), 120-127. https://doi.org /10.1080/08964289.2015.1045823 